Studia z Dziejów Średniowiecza, t. 23, 2019

\author{
Sergiej Polechow \\ (Instytut Historii Rosji Rosyjska Akademia Nauk)
}

\title{
Rahoza. Przyczynek do dziejów kancelarii i dworu wielkich książąt litewskich w epoce Witolda
}

https://doi.org/10.26881/sds.2019.23.10

Keywords: grand duke Vytautas, Grand Duchy of Lithuania, medieval chancery, medieval prosopography and genealogy, Teutonic Order

W ostatnich latach badacze ponownie zwrócili się ku problematyce dworu i kancelarii wielkiego księcia litewskiego Aleksandra Witolda. Specjalne badania poświęcono kształtowaniu się, składowi personalnemu mieszkańców i życiu codziennemu dworu wielkoksiążęcego, pochodzeniu, powiązaniom i karierom dworzan i personelu kancelarii Witolda ${ }^{1}$, produkcji kancelaryjnej - dokumentom i listom, ich

1 S. Szybkowski, Kariera Mikołaja Cebulki z Czechowa w stużbie wielkiego księcia Witolda, 1407-1430, „Gdańskie Studia z Dziejów Średniowiecza” 1996, t. 3, s. 253-320; idem, Pozakancelaryjne aspekty życia Mikołaja Cebulki z Czechowa-sekretarza, dyplomaty $i$ doradcy Witolda. Przyczynek do badań nad kręiem polskich wspótpracowników wielkiego księcia [w:] SPśs, t. 7, s. 243-265; idem, Krzyżacki szpieg, lubelski mieszczanin $i$ sandomierski choraży. Kilka uwag $w$ sprawie badań prozopograficznych personelu kancelarii wielkiego księcia Witolda, „Gdańskie Studia z Dziejów Średniowiecza” 1997, t. 4, s. 247-278; idem, Polish staff as a social group in the Chancery of Grand Duke Witold, „Quaestiones Medii Aevi Novae” 1998, vol. 3, s. 75-94; idem, Kancelaria wielkiego księcia Witolda $w$ dobie wielkich konfliktów z zakonem krzyżackim w latach 1409-1422. Organizacja, zadania, personel [w:] Kancelaria wielkich mistrzów i Polska kancelaria królewska $w$ XV wieku, red. J. Trupinda, Malbork 2006, s. 299-318; idem, Rycerscy goście z Polski na dworze wielkiego księcia Witolda-próba portretu grupy [w:] Litwa i jej sasiedzi w relacjach wzajemnych (XIII-XVI w.), red. A. Kołodziejczyk, R. Kubicki, M. Radoch, Olsztyn-Gdańsk 2014, s. 81-105; R. Čapaitè, The Everyday Life of Grand Duke Vytautas of Lithuania According to Contemporary Corespondence, „Lithuanian Historical Studies” 2003, vol. 8, s. 1-27; eadem, Ślazacy na dworze wielkiego księcia litewskiego w pierwszej połowie XV wieku [w:] Podróże i migracje w Europie 
formularzowi i paleografii ${ }^{2}$. Należy podkreślić, że podstawę tych studiów stanowią przeważnie dokumenty i listy pisane po łacinie i niemiecku, podczas gdy znacznie mniej uwagi poświęca się piśmiennictwu ruskiemu. Ma to obiektywna przyczynę, dobrze znana wszystkim badaczom dziejów Wielkiego Księstwa Litewskiego - stan zachowania źródeł, które przetrwały w większości w archiwach krajów zachodniego kręgu kulturowego, co decyduje o tym, że badania nad dyplomatyką i epistolografią z czasów wspomnianego władcy maja stosunkowo jednostronny charakter. Dla porównania, obecnie znamy niespełna 20 dokumentów ruskich Witolda, z nich zaledwie 8 zachowało się w oryginałach, co pozwala na wszechstronne zbadanie ich cech, w tym paleograficznych i językowych ${ }^{3}$, podczas gdy samych oryginałów listów i dokumentów łacińskich i niemieckich istnieje więcej niż $200^{4}$. Tym cenniejsza jest każda wzmianka dotycząca

Środkowej, red. A. Barciak, Katowice-Zabrze 2012, s. 48-56; R. Petrauskas, Vytauto dvaras: struktūra ir kasdienybe , „Naujasis Židinys - Aidai” 2003, nr. 1-2, s. 39-44; idem, Didžiojo kunigaikščio institucinio dvaro susiformavimas Lietuvoje (XIV a. pabaigoje - XV a. viduryje), „Lietuvos istorijos metraštis” 2005, t. 1, s. 5-38 (tłum. polskie: Kształtowanie się instytucji dworu wielkoksiażęcego $w$ Wielkim Księstwie Litewskim (koniec XIV-połowa XV wieku), „Politeja” 2011, nr 2 (16), s. 155-185).

2 R. Čapaitè, Vytauto laiškai kaip Viduramžiu epistolinio žanro pavyzdys [w:] Metraščiai ir kunigaikščiu laiškai (Senoji Lietuvos literatūra, kn. 4), Vilnius 1996, s. 47-95; eadem, Gotikinis kursyvas Lietuvos didžiojo kunigaikščio Vytauto raštinèje, Vilnius 2007; eadem, List jako narzędzie komunikacji wielkiego księcia litewskiego Witolda, SŹ 2012, t. 50, s. 41-56; А.И. Груша, Документальная письменность Великого Княжества Литовского (конеи XIV - первая треть XVI в.), Минск 2015. Warto odnotować, że wciąż zachowują znaczenie klasyczne prace: A. Vasiliauskas, Vytauto Didžiojo diplomatika, „Senovë” 1936, kn. 2, s. 175-214; 1938, kn. 4, s. 133-172; W. Kuraszkiewicz, Gramoty XIV-XV wieku. Studjum filologiczne, „Byzantinoslavica” 1932, roč. 4, s. 335-364; M. Kosman, Kancelaria wielkiego księcia Witolda, SŹ 1969, t. 14, 1969, s. 91-119; idem, Dokumenty wielkiego księcia Witolda, SŹ 1971, t. 16, s. 139-169.

3 Vitoldiana. Codex privilegiorum Vitoldi magni ducis Lithuaniae, 1386-1430, wyd. J. Ochmański, Warszawa-Poznań 1986, nr 16, 17, 39, 102, 109, 112, 177, 180; por. S. Szybkowski, Polish Staff..., s. 90-91; С.В. Полехов, Загадка гралотьь Buтовта (Vitoldiana, № 11): XIV или XIX век?, „Словене” 2018, т. 7, № 2, s. 272-297. Warto zaznaczyć, że wskazana edycja ma znaczenie głównie jako punkt odniesienia, który dobrze systematyzuje stan wiedzy o dokumentach Witolda w końcu lat 80. minionego wieku. Natomiast ich teksty w większości zostały przedrukowane z poprzednich edycji, nawet gdy zachowały się oryginały (por. bardzo krytyczną recenzję Egidijusa Banionisa: „Lietuvos istorijos metraštis” 1987, s. 142-147). W wypadku tekstów ruskich bardzo krytyczie należy ocenić to, że oddano je w transliteracji łacińskiej, co uniemożliwia korzystanie z edycji na potrzeby badań filologicznych.

4 Zob. ich listę: R. Čapaitè, Gotikinis kursyvas..., s. 492-518. Do dokładnie 204 wymienionych tu dokumentów i listów zachowanych jako oryginały można dodać jeszcze co najmniej trzy listy: do mistrza inflanckiego z 13 stycznia, bez 
sposobów komunikacji Witolda z jego ruskimi poddanymi i sąsiadami oraz ruskiego oddziału kancelarii wielkoksiążęcej ${ }^{5}$.

Wskazane problemy zachowują aktualność również dla czasów spadkobierców Witolda. Istotny wydaje się problem zmian zachodzących wraz ze zmiana na tronie monarszym. W starszej literaturze przyjmowano, że książę Bolesław Świdrygiełło po objęciu litewskiego stolca wielkoksiążęcego zaczą protegować Rusinów. Podstawą takiego wniosku było stwierdzenie w liście biskupa krakowskiego Zbigniewa Oleśnickiego do Juliana Cezariniego napisanym na początku 1432 r., a na jego poparcie przywoływano listę gwarantów układu Świdrygiełły z zakonem niemieckim zawartego w Skirstymoniu 15 maja 1432 r., w którym w charakterze gwarantów występowali liczni prawosławni poddani wielkiego księcia. Jednak szczegółowe badania wykazały, że ten układ został zawarty jako dodatkowy na żądanie wielkiego mistrza Pawła von Rusdorfa. Ten bowiem chciał umocnić swoja pozycję w Prusach i w związku z tym zależało mu na poszerzeniu listy gwarantów o przedstawicieli stanów pruskich (bez których zgody zawarł pierwotnie sojusz zaczepno-odporny z Litwa). Analogicznie - podobną formę musiał przybrać litewski dokument tego traktatu. Analiza składu otoczenia Świdrygiełły w okresie wielkoksiążęcym, czyli w latach 1430-1432, nie potwierdziła oskarżeń o popieranie Rusinów, artykułowanych pod jego adresem ze strony biskupa krakowskiego. Okazało się, że najwyższe urzędy nadal piastowali ci sami panowie litewscy, którzy tworzyli otoczenie Witolda. Jednak u boku Świdrygiełły pojawiło się

daty rocznej, wystawiony między rokiem 1394 a 1406 (Полоцкие гралоты XIIIначала XVI века, подг. А.Л. Хорошкевич, С.В. Полехов и др., т. 1, Москва 2015, nr 30), do wielkiego marszałka zakonu z 29 V 1414 (GSPK, Ordensbriefarchiv [dalej: OBA], nr 2167), do rajców wrocławskich z 6 II 1416 (R. Stelmach, Listy i dokumenty Jagiellonów w WAP we Wroctawiu (1413-1503), „Teki Archiwalne” 1981, t. 18, s. $16-17$ i podobizna).

5 Oto M. Kosman (Kancelaria wielkiego księcia Witolda...), poświęcił oddziałowi ruskiemu tylko jedną z prawie 30 stron (s. 112-113). Czasami takie wzmianki spotykamy w korespondencji dostojników zakonu niemieckiego, np. w styczniu $1423 \mathrm{r}$. wielki marszałek zakonu niemieckiego Ludwig von Landsee pisał do króla rzymskiego Zygmunta Luksemburskiego, że w poselstwie Witolda i Władysława Jagiełły do „cesarza tatarskiego" i Turków bierze udział pisarz ruski Witold (GSPK, OBA, nr 4060; druk: Scriptores rerum Silesiacarum, Bd. 6, hrsg. C. Grünhagen, Breslau 1871, nr 47). 24 lipca 1433 r. natomiast prokurator Lochstedt książę Konrad (VIII) Oleśnicki informował wielkiego mistrza Pawła von Rusdorfa o przybyciu do Królewca sześciu Rusinów, z których jeden był niegdyś pisarzem Świdrygiełły, wziętym do niewoli podczas jego obalenia w poprzednim roku (GSPK, OBA, nr 6587). 
kilka nowych osób, których pochodzenie nie zawsze jest jasne. Poruszyłem ten problem w swojej książce poświęconej dziejom Wielkiego Księstwa Litewskiego w latach trzydziestych XV w. ${ }^{6}$ Nowe badania pozwalają dodać do tego istotne szczegóły. Otóż niejaki Nostewitz poświadczony przy Świdrygielle w latach 1420 i 1431 najprawdopodobniej pochodził ze znanej rodziny ślaskiej ${ }^{7}$, a nie z Rusi, jak wtedy przypuszczałem (zwłaszcza że pojawia się w źródłach dotyczących kontaktów Świdrygiełły ze Ślaskiem i Czechami). Niewyjaśnione zaś pozostaje pochodzenie marszałka nadwornego Michała oraz „największego ulubieńca" hospodarskiego Andrzejka, którzy posłowali do Władysława Jagiełły odpowiednio w październiku 1431 i sierpniu 1432 r. ${ }^{8}$ Wydaje się zatem, że warto kontynuować dociekania dotyczące „nowych ludzi” w otoczeniu wielkiego księcia Świdrygiełły. $\mathrm{Na}$ tematyce tej skupię się w niniejszym przyczynku poświęconym analizie nowo odnalezionego źródła z zasobów historycznego archiwum królewieckiego (obecnie w Berlinie), które rzuca światło na pochodzenie innego „nowego człowieka” z otoczenia wspomnianego władcy Litwy - Rahozy.

Rahoza kilkakrotnie występuje w źródłach z lat 1431-1432 jako osoba zaufana Świdrygiełł: w początkach czerwca 1431 r. posłował razem z pisarzem hospodarskim do wielkiego mistrza w sprawie zjazdu ${ }^{9}$, w połowie sierpnia tegoż roku - razem z panem litewskim Andruszka

6 Zob. С.В. Полехов, Наследники Витовта. Династическая война в Великом княжестве Литовскол в 30-е годь ХV века, Москва 2015, s. 148-258 (tu też źródła i literatura).

7 Wskazał na to już R. Petrauskas, Tarp riteriško mobilumo ir indigenato: svetimšaliai riteriai Lietuvos didžiojo kunigaikščio dvare XV a. pirmojoje pusejje [w:] Krikščioniu visuomenès raidos atodangos LDK vakarinèje dalyje ir Prūsijoje: nuo užuomazgos iki brandos, sud. M. Ščavinskas, Klaipeda 2015, s. 189 (przedruk w: idem, Lietuvos Didžioji Kunigaikštystè. Politika ir visuomenè vélyvaisiais Viduramžiais, Vilnius 2017, s. 354-355). Ze Śląska wywodzi też Smolnę - niestety, bez wskazania źródła (ibidem, s. 188, przedruk, s. 352).

8 R. Petrauskas, Didžiojo kunigaikščio institucinio dvaro susiformavimas..., s. 25, 30. Co do Andrzejka, to R. Petrauskas opowiada się za jego tożsamością z marszalkiem Świdrygiełły Andrzejem Dżusa (Czusa), który pochodził ze znanego rodu wołyńskiego i później był posłem do wielkiego mistrza, ale nie w październiku 1432 r., jak twierdzi badacz litewski, lecz rok później (GSPK, OBA, nr 6236, 6701; С.В. Полехов, Наследники Витовта..., прим. 780, s. 240; прим. 140, s. 286; s. 590) - nie jest zatem wykluczone, że w otoczeniu Świdrygiełły pojawił się dopiero po jego obaleniu, gdy miały zacieśnić się jego kontakty z ruskimi stronnikami.

9 GSPK, OBA, nr 5649; druk: Codex epistolaris saeculi decimi quinti (dalej: CEXV), t. 2, wyd. A. Lewicki, Kraków 1891, nr 190. 
Niemirowiczem do króla polskiego w sprawie zawieszenia broni w toczacej się wtedy wojnie o Wołyń ${ }^{10}$. Dnia 6 września tego roku ręczył przed królem za jeńców litewskich ${ }^{11}$, a na przełomie stycznia i lutego $1432 \mathrm{r}$. wspólnie z namiestnikiem nowogródzkim Pietraszem Montygierdowiczem i sekretarzem wielkiego księcia pertraktował z Polakami w sprawie glejtu dla posłów zakonnych i mołdawskich, którzy zdaniem Świdrygiełły mieli wziąć udział w zjeździe polsko-litewskim przeznaczonym na 2 lutego, co jednak skończyło się na niczym ${ }^{12}$. Potem imię Rahozy znika ze źródeł. Pozostaje niejasne, czy jest tożsamy z Rahoza Jakszyczem, który w połowie XV w. otrzymał od Kazimierza Jagiellończyka nadanie 10 chłopów ${ }^{13}$. To wszystko pozwoliło Rimvydasowi Petrauskasowi na stwierdzenie, że Rahoza był osobą z otoczenia Świdrygiełły ${ }^{14}$.

O tym, że z pochodzenia był Rusinem lub spędził wiele czasu na Rusi, niewatpliwie świadczy jego imię albo przydomek. Słowo „ragoza” (albo „rahoza” w wymówieniu krtaniowym) ${ }^{15}$ miało w języku ruskim trzy znaczenia: 1) kłótnia, sprzeczka (ссора, свара), a także osoba skłonna do takiego zachowania (сварливый человек); 2) rodzaj rośliny - pałka (рогоз, łac. Typha); 3) szorstka tkanina (рогожа) ${ }^{16}$. Osoby i rodziny o tym przydomku występują w XV-XVII w. zarówno na północnym wschodzie, północnym zachodzie Rusi ${ }^{17}$, jak i w Wielkim Księstwie Litewskim, gdzie najbardziej znanym przykładem

10 GSPK, OBA, nr 5719; odpis: GSPK, Ordensfoliant (dalej: OF) 14, s. 627-629; druk: Kodeks dyplomatyczny Litwy, wyd. E. Raczyński, Wrocław 1845, s. 352-354 (gdzie zniekształcono jego imię).

11 AGAD, dokumenty pergaminowe, nr 4451; druk: CEXV, t. 1, cz. 1, wyd. A. Sokołowski, J. Szujski, Kraków 1876, nr 73.

12 GSPK, OF 14, s. 693.

13 Lietuvos Metrika. Knyga Nr. 3 (1440-1498). Užrašymu knyga 3, par. L. Anužytè, A. Baliulis, Vilnius 1998, s. 26.

14 R. Petrauskas, Lietuvos diduomene XIV a. pabaigoje - XV a.: Sudetis -struktūra - valdžia, Vilnius 2003, s. 283.

15 Przeważnie w takiej formie jego imię zapisywano w źródłach niemieckich i łacińskich (zob. wskazówki wyżej).

16 В.И. Даль, Толковый словарь живого великорусского языка, т. 4, Санкт-Петербург-Москва 1882, s. 7, por. s. 98-99 (tu też inne znaczenia); С.Б. Веселовский, Оноластикон: Древнерусские илена, прозвища и фбалилии, Москва 1974, s. 265; Словарь русского языка XI-XVII вв., вып. 21, Москва 1995, s. 119-120; por. Словарь древнерусского языка (XI-XIV вв.), т. 9, Москва 2012, s. 455 (рагозьнъ - „враждующий”).

17 С.Б. Веселовский, Оноластикон..., s. 265; Н.М. Тупиков, Словарь древнерусских личных собственных илён, изд. 1, Санкт-Петербург 1903, s. 388, 774-775 (przedruk: Москва 2005, s. 356, 742-743). 
jest bodajże metropolita kijowski Michał Rahoza, jeden z twórców unii brzeskiej 1596 r., który pochodził z rodu szlacheckiego osiadłego na Połocczyźnie i Mińszczyźnie ${ }^{18}$. Pisząc wspomnianą książkę, uważałem, że Rahoza pochodził z Czernihowszczyzny ${ }^{19}$, opierając się na wpisie w pomjaniku ławry peczerskiej w Kijowie („Род з Новагородка Съверского Рагозинъ”) ${ }^{20}$, co dobrze wpisywałoby się w biografię Świdrygiełły, który przed objęciem tronu hospodarskiego miał główne posiadłości właśnie w tej części Wielkiego Księstwa Litewskiego. Jednak pomjaniki są źródłem bardzo niepewnym i bałamutnym $^{21}$, a wspomniany pomjanik (kontynuowany do 1526 r.), aczkolwiek zawiera dane o osobach od XI w., został odtworzony przez mnichów z ławry z pamięci po słynnym najeździe chana krymskiego Mengli-Gireja na Kijów z 1482 r., w wyniku którego jego archetyp uległ zniszczeniu ${ }^{22}$.

Nowych, dokładniejszych danych o Rahozie dostarcza źródło przechowywane w zasobach archiwum królewieckiego, mianowicie streszczenie listu wielkiego księcia litewskiego Witolda do wielkiego mistrza zakonu niemieckiego ${ }^{23}$. Aby w sposób właściwy zrozumieć jego treść, najpierw warto poświęcić uwagę datacji listu, której streszczenie nie zawiera. Streszczenie to jest umieszczone na jednej stronie karty papierowej, której drugą stronę zajmuje wyciag z listu biskupa Liège pod nagłówkiem „Bisschoff czu Luttich schreibet”. Filigran - róg myśliwski - w albumie Gerarda Piccarda ma najbliższe odpowiedniki w drugiej i trzeciej dekadzie XV w., przy czym w Europie Środkowej i Wschodniej podobny filigran jest poświadczony na przełomie drugiej i trzeciej dekady tego stulecia. W regestach odpowiedniej części archiwum królewieckiego

18 В.С. Пазднякоў, Архіў праваслаўных $і$ грэка-каталіцкіх мітрапалітаў Вялікага Княства Літойскага ў XVI-XVIII стст. (гісторыя, структура, склад), Мінск 2014, s. 120.

19 С.В. Полехов, Наследники Витовта..., s. 189.

20 С.Т. Голубев, Древний полянник Киево-Печерской лавры (кониа XV и начала XVI cm.) [w:] Чтения в историческом обществе Нестора летописиа, кн. 6, Киев 1892, s. I-XIV, 1-88, tu s. 64.

21 D. Dąbrowski, Genealogia Mścistawowiczów, Kraków 2008, s. 33-35 (tu też literatura zagadnienia).

22 С.Т. Голубев, Древний помянник..., s. VIII-IX. O najeździe Mengli-Gireja zob. ostatnio: В.П. Гулевич, "Київська трагедія» 1482 р.: міфби й ббакти, „Український історичний журнал” 2013, № 5, s. 89-101.

23 GSPK, OBA, nr 2873, edycja zob. aneks. 
(Ordensbriefarchiv) streszczenia obu listów zostały umieszczone pod datą ustaloną przez wydawców jako „(1418 Ende)”24.

Jak wynika ze streszczenia, w liście Witolda była mowa o złodziejach zbiegłych do władztwa zakonu niemieckiego, mianowicie do Ragnety, podczas zjazdu wielkiego księcia z wielkim mistrzem, który odbywał się prawdopodobnie na pewnej wyspie. Mieli oni wówczas ukraść wielkiemu księciu cenne przedmioty, co przysięga potwierdził Rahoza, określony w źródle jako „nasz najwyższy pisarz ruski” („unsir obirster Ruwssche schreiber Rahoza”). Pośrednio o datacji interesującego nas tu pisma Witolda świadczy streszczenie listu biskupa Liège umieszczone na innej stronie tej samej karty. Biskupem tym był Jan von Wallenrode, a jego list, jak wykazał Bernhart Jähnig, pochodził z 1418 r. ${ }^{25}$ Już ta okoliczność pozwala przypuszczać, że list Witolda był efektem zjazdu odbytego w Wielonie 13-22 października 1418 r. Poza Witoldem brali w nim udział król polski Władysław Jagiełło, wielki mistrz Michał Küchmeister oraz mistrz inflancki Zygfryd Lander von Sponheim w otoczeniu dostojników i obserwatorów ${ }^{26}$. Jak wynika z listu wielkiego mistrza do prokuratora zakonnego przy kurii papieskiej z 24 lutego 1419 r., jeszcze podczas zjazdu Witold stwierdził, że kilku Rusinów (zapewne tych, którzy mieli być obecni na zjeździe) zbiegło odeń i przez posła zażądał od wielkiego mistrza ich wydania, co ten przyrzekł uczynić w razie, gdy się u niego zjawią ${ }^{27}$. Dopiero po powrocie ze zjazdu, już w Ragnecie, spotkał wielki mistrz trzech Rusinów, którzy przybyli tam na mocy glejtu wystawionego przez ragneckiego komtura zamkowego i następnie za zgodą zwierzchnika zakonu zostali wpuszczeni do zamku. Wkrótce miał dowiedzieć się o tym Witold, ponieważ zażądał od wielkiego mistrza wydania tych zbiegów, zwłaszcza że okazało się, iż ukradli Witoldowi sporo ubrań, kosztowności

24 RHD, Bd. 1/1, nr 2873.

25 Zob. B. Jähnig, Johann von Wallenrode O.T. Erzbischof von Riga, Königlicher Rat, Deutschordensdiplomat und Bischof von Lüttich im Zeitalter des Schismas und des Konstanzer Konzils (um 1370-1419) (Quellen und Studien zur Geschichte des Deutschen Ordens, Bd. 24), Bonn-Godesberg 1970, s. 146-147.

26 Źródła i literaturę dotyczącą tego zjazdu podaje A. Szweda, Organizacja i technika dyplomacji polskiej $w$ stosunkach $z$ zakonem krzyżackim $w$ Prusach $w$ latach 1386-1454, Toruń 2009, s. 388-389.

27 Die Berichte der Generalprokuratoren des Deutschen Ordens an der Kurie (dalej: BGDO), Bd. 2, Bearb. H. Koeppen, Göttingen 1960, nr 309; por. Codex epistolaris Vitoldi Magni ducis Lithuaniae: 1376-1430, wyd. A. Prochaska, Kraków 1882 (dalej: CEV), nr 819. 
(„kleinot”), pieniędzy i innego mienia. Żądanie takie padło w liście wielkoksiążęcym napisanym zapewne pod koniec października albo na początku listopada; list ten nie zachował się, jego treść jest znana $\mathrm{z}$ dalszej korespondencji w tej sprawie ${ }^{28}$. Wielki mistrz odpowiedział 11 listopada, że chętnie by ich wydał, ale nie może tego uczynić, bo wolny przejazd został im zagwarantowany przez komtura zamkowego Ragnety, czego on nie może naruszać ${ }^{29}$. Odpowiedź Witolda, która także się nie zachowała, miała być bardzo ostra (sam jej ton stał się jednym z przedmiotów dalszej dyskusji); reagując na nia, wielki mistrz dodał, że zbiegów tych nie było na zjeździe, bo wtedy by ich wydał, żadnych natomiast kosztowności ze sobą nie mieli ${ }^{30}$. Datę kolejnego listu Witolda, 14 grudnia 1418 r., znamy z kolejnej odpowiedzi wielkiego mistrza z 7 stycznia 1419 r., w której znajdujemy w zasadzie te same argumenty uzupełnione o oskarżenie, że Witold nie wydaje wielkiemu mistrzowi zbiegłych do niego braci zakonu mimo obowiązywania stosownych bulli papieskich ${ }^{31}$. Następnie, w czasie przerwy w korespondencji władców spowodowanej wyjazdem Witolda do jego „dalekich ziem ruskich”32, zwierzchnik zakonu dowiedział się z listu prokuratora przy kurii papieskiej, że wielki książę przesłał papieżowi odpis jego listu z 11 listopada, skarżąc się na wielkiego mistrza ${ }^{33}$. Jakkolwiek nie mamy bezpośrednich wskazówek w źródłach, wydaje się wysoce prawdopodobne, że Witold mógł posłużyć się retoryką religijna, oskarżając wielkiego mistrza o sprzyjanie „schizmatykom”. Z kolei Kiejstutowicz,

28 CEV, nr 812, 814. Ceduła niezachowanego listu Witolda, którą Antoni Prochaska odniósł do tej samej sprawy i datował na listopad 1418 r. (CEV, nr 810), pewnie nie ma z nią związku. Przemawia za tym kilka argumentów. Po pierwsze, ta ceduła jest pisana według klasyfikacji Rūty Čapaitè, „dziewiątą ręką” oddziału łacińsko-niemieckiego kancelarii Witolda, a dokumenty i listy spisane przez tego pisarza są znane dopiero z 1421 r. i lat następnych (R. Čapaitè, Gotikinis kursywa..., s. 364-380, 511, nr 143 - GSPK, OBA, nr 4791). Po drugie, chodzi w niej nie o Rusinów zbiegłych do Prus i oskarżanych o kradzież, lecz o Niemca Michała "Czekuna”, także sługę Witolda, u którego dowodnie znaleziono ukradzione rzeczy i to w Wilnie. Po trzecie, wymioniony tu Hans Fochs jest wspomniany w służbie Witolda dopiero od 1423 r. (R. Petrauskas, Didžiojo kunigaikščio institucinio dvaro susiformavimas..., s. 28-29).

29 CEV, nr 812.

$30 \quad$ Ibidem, $\mathrm{nr} 814$.

31 Ibidem, nr 819.

32 Ibidem, nr 826.

33 BGDO, Bd. 2, nr 303; odpowiedź wielkiego prokuratora z 24 lutego zachowała się w postaci konceptu - ibidem, nr 309. 
odpowiadajac na list wielkiego mistrza dopiero 9 marca 1419 r., po powrocie z Rusi, znowu zarzucał mu, że ten mimo wielokrotnych obietnic nie wydaje mu zbiegów, i zgodnie z wcześniejszymi wypowiedziami podkreślał, że ich przyjęcie nie mogło odbyć się bez wiedzy i woli zwierzchnika zakonu. W przypadku braci zakonu do niego zbiegłych przyznaje, że mógłby wcześniej o nich napisać, ale ich ucieczka na Litwę nie miała miejsca podczas pokojowych pertraktacji w Wielonie. Wielki książę reasumował, że wydanie zbiegów mogłoby stanowić gest dobrej woli ze strony wielkiego mistrza, ale skoro on tego nie chce, to Witold też nie będzie robił takich gestów pod jego adresem ${ }^{34}$. Ostatni list wielkiego mistrza, będący odpowiedzią na to pismo Witolda ${ }^{35}$, faktycznie nie przynosi już nic nowego. W dalszej korespondencji brak odniesień do tej sprawy, co sugeruje, że temat został wyczerpany.

Dzięki zachowanym odpowiedziom wielkiego mistrza możemy dokładnie uchwycić moment, w którym został napisany list Witolda, zachowany $\mathrm{w}$ postaci streszczenia. Zwraca bowiem uwagę zbieżność niektórych miejsc z listu wielkiego mistrza z 7 stycznia 1419 r. i streszczenia listu Witolda:

$34 \mathrm{CEV}, \mathrm{nr}$ 826. Zapewne ten sam list został streszczony w rękopisie XVI-wiecznym pochodzącym z kancelarii wielkomistrzowskiej, ale z błędną datą dzienna, zepsuta na skutek niepełnego odczytania - „Anno 1419 am suntag Invocavit” zamiast „am donrstage noch deme suntage, als man singet Invocavit, im XIIII ${ }^{\mathrm{C}}$ und newnczendem iare" (Lietuvos mokslu akademijos Vrublevskiu bibliotekos Rankraščiu skyrius (dalej: LMAVB RS), F 15-73, s. 164; o rękopisie zob. K. Kwiatkowski, Neue Quellen aus dem Kreis des Deutschen Ordens zum Krieg von 1409-1411 (Teil 1), ZH 2010, t. 75, s. 67-112). Przemawia za tym nie tylko bardzo dokładna zbieżność treści, ale także okoliczność, że Witold usprawiedliwia długi brak odpowiedzi pobytem na Rusi, z czego wynika, że raczej nie pisał do wielkiego mistrza cztery dni wcześniej.

$35 \mathrm{CEV}, \mathrm{nr}$ 829. List ten w odpisie w registrancie (OF) $\mathrm{nr}$ 10, od $1944 \mathrm{r}$. zaginiony, nie miał daty dziennej, a był umieszczony między listami wielkiego mistrza z datą od 7 stycznia do połowy marca 1419 r. (GSPK, Findmittel, Findbuch 66, k. 140, 143, 144, nr 85-87 et seq.). Antoni Prochaska datował go na koniec marca tego roku, natomiast Hans Koeppen próbował przesunąc datę na czas przed 24 II 1419 r., kiedy wielki mistrz dowodnie wiedział o skardze Witolda przed papieżem i odpowiadał w tej sprawie prokuratorowi zakonnemu (BGDO, Bd. 2, nr 309, przyp. 9). Zwierzchnik zakonu mógł go istotnie wtedy podyktować, ale wcale nie musiał, zwłaszcza że rzeczywiście jest zbieżny w tematyce i szczegółach z listem Witolda z 9 marca. Ze względu na czas dotarcia listów z Wilna i Trok do Prus ostatnią odpowiedź Küchmeistra należałoby datować na połowę albo początek drugiej połowy marca $1419 \mathrm{r}$. Badacz litewski Antanas Vasiliauskas oceniał czas dostarczenia listu z Wilna do Malborka na trzy-cztery dni, zob. R. Čapaitè, Istorikas Antanas Vasiliauskas (Vasys) (1902-1974), „Mūsu praeitis” 1992 , t. 2 , s. 72 . 


\begin{tabular}{|c|c|}
\hline Streszczenie listu Witolda & Odpowiedź wielkiego mistrza \\
\hline $\begin{array}{l}\text { Czum ersten, wir us euwirm briff } \\
\text { czien, das ir ungutlichin von uns ufge- } \\
\text { nomen habt, als wir euch von den dreyn } \\
\text { dyeben vorgeschreben haben, das euwir } \\
\text { gute meynunge ofte czu ungutten wurden } \\
\text { gewand. }\end{array}$ & $\begin{array}{l}\text { Euwern brif uns gesant und am nehist } \\
\text { geleden sente Lucien tage czu Puna gege- } \\
\text { ben, haben wir wol vornomen, in deme } \\
\text { euwir hirlichkeit uns antwert alz uf den } \\
\text { unsern, wie ir us unsern brifen czihet, das } \\
\text { wir unguttlichen hetten von der dreier } \\
\text { dibe wegen ufgenomen euwern schrif- } \\
\text { ten etc. }\end{array}$ \\
\hline $\begin{array}{l}\text { Item, wir nemet, das euch das etwas } \\
\text { beweget, als wir in unsirm neesten briff } \\
\text { euch geschrebin habin, also ir schriebt } \\
\text { ok uns als deme, der nicht vornuft hette. }\end{array}$ & $\begin{array}{l}\text { Sundir alz euwer grosmechtikeit vor- } \\
\text { dan volfuret, wie ir vornemet, das uns } \\
\text { euwir eigene schriffte dorczu sulden } \\
\text { beweget haben mit sulchen worten etc., } \\
\text { das wir euwir herlichkeit doruff geschre- } \\
\text { ben hetten, alz deme, der nicht vornunft } \\
\text { hette etc. }\end{array}$ \\
\hline
\end{tabular}

Na samym początku swojej odpowiedzi wielki mistrz przytacza datę listu Witolda - został napisany w dzień św. Łucji w Puni, a więc 14 grudnia 1418 r. Ewidentnie stanowił odpowiedź na poprzedni list wielkiego mistrza do Witolda napisany 3 grudnia $^{36}$.

Jak z tego wynika, celem streszczenia było ułatwienie sporządzenia odpowiedzi. Zwraca przy tym uwagę jeszcze jedna okoliczność: punkty streszczenia oznaczone są na lewym marginesie literami i różnymi znaczkami, ale krzyżyki w kole są tylko przy przytoczonych punktach, z których wyciagi dosłownie przejęto do odpowiedzi, aby się do nich odnieśćc ${ }^{37}$. W dalszym ciagu odpowiedzi już nie odnoszono się bezpośrednio do listu Witolda, lecz wysunięto nowe zarzuty - o nieodsyłanie z Litwy do Prus zbiegłych braci zakonu, którzy w Wielkim Księstwie zawarli związki małżeńskie. Właśnie na taką funkcję streszczenia listu Witolda wskazuje również to, iż w inwentarzu archiwalnym (Findbuch 66), zawierającym regesty z niezachowanego Ordensfoliant 10, znajdujemy odpowiedź biskupowi Liège Janowi von Wallenrode napisana 22 stycznia $1419 \mathrm{r}$., zatem kilka tygodni po powstaniu odpowiedzi skierowanej do litewskiego władcy: „Der Hochmeister

\footnotetext{
36 CEV, nr 814.

37 Zob. o podobnej praktyce w korespondencji Witolda: R. Čapaitè, Vytauto laiškai..., s. 74-76; eadem, List jako narzędzie komunikacji..., s. 45.
} 
beglückwünscht den Bischof v. Lüttich (früher Erzbischof v. Riga) zu seiner Ernennung, bespricht alle von ihm an den Orden erhobenen Forderungen, weist sie als unbegründet zurück und bittet ihn, den Orden nicht zu beschuldigen. Slochow am tage Vincencii 1419"38. Nie będzie więc przesadą twierdzenie, że tym pismem wielki mistrz odpowiedział na list biskupa Liège streszczony na tej samej karcie co omawiany tu list Witolda.

Czego można się dowiedzić odnośnie do Rahozy z przytoczonego listu, w którym został określony jako „najwyższy ruski pisarz” wielkiego księcia? Ze źródła tego zdaje się wynikać, iż kancelaria Witolda już przed 1418 r. miała tak rozbudowaną strukturę, że w jej skład wchodził cały „oddział ruski” mający własną hierarchię pracowników, na którego czele stał najwyższy pisarz ruski. Tę funkcję, może już przed 1418 r., sprawował Rahoza. Nie można wykluczyć, że jego pozycja odpowiadała miejscu sekretarzy/notariuszy w oddziale łacińsko-niemieckim: mieli mu podlegać skrybowie zajmujacy się bezpośrednio spisywaniem dokumentów ${ }^{39}$ (odpowiednik diaków oddziału ruskiego ${ }^{40}$ ), ale sam w hierarchii kancelaryjnej stał niżej od panów litewskich odpowiedzialnych za wystawienie dokumentów, takich jak starosta, a później wojewoda wileński Wojciech Moniwid albo starosta podolski Jan Dowgird. Już sama niepewność pochodzenia Rahozy świadczy o tym, że karierę zawdzięczał pracy kancelaryjnej. Skoro swoja przysięga potwierdzał kradzież cennych rzeczy przez sługi Witolda, to istniał związek personalny między kancelarią a służbą dworską - niewykluczone, że Rahoza był przełożonym tych Rusinów, a przynajmniej w jakiś sposób podtrzymywał z nimi kontakt ${ }^{41}$. To nie powinno dziwić ze względu na potrzebę komunikacji na wielonarodowym dworze Witolda. Ponadto przysięga Rahozy dowodzi, iż cieszył się zaufaniem władcy, w którego służbie pozostawał także po $1418 \mathrm{r}$. i to nadal jako pracownik kancelarii, o czym przekonuje niebudzące wątpliwości źródło.

38 GStAPK, Findmittel, Findbuch 66, k. 139 - dawniej OF 10, nr 340.

39 M. Kosman, Kancelaria wielkiego księcia Witolda..., s. 101-104; S. Szybkowski, Kancelaria wielkiego księcia Witolda..., s. 304-305; idem, Polish Staff..., s. 85-86.

40 Najobszerniej zob. A.I. Груша, Канцьлярыя Вялікага княства Літоўскага 40-x гадоў XV-першай паловы XVI cm., Мінск 2006, s. 44-62, 138-165.

41 Zapewne zbiegiem okoliczności należy tłumaczyć pomyłkę w wywodzie Marcelego Kosmana (Kancelaria wielkiego księcia Witolda..., s. 112), który pisze o skrybach w oddziale ruskim kancelarii Witolda, identyfikując ich ze zbiegami z przełomu lat 1418 i 1419. Jednak w przytoczonych listach, na które powołuje się wspomniany badacz, żaden z nich nie został określony w taki sposób. Prawdopodobnie badacz pomylił czasownik „schreiben” z rzeczownikiem „Schreiber”. 
Chodzi mianowicie o dokument Witolda dla niejakiego Sanka z 22 sierpnia 1424 r., wystawiony podczas podróży na południe Wielkiego Księstwa Litewskiego, w Ołtuszkowie na Podolu Zachodnim, które Witold otrzymał w dożywocie od Władysława Jagiełły, ale usiłował umocnić tam swoją władze, m.in. poprzez nadania dla miejscowych bojarów i szlachty ${ }^{42}$. W kontekście powyższych rozważań zwraca uwage podpis $\mathrm{w}$ prawym dolnym rogu karty pergaminowej. Jerzy Ochmański, który jako jedyny wydał ten dokument w Vitoldianach (niestety, w transliteracji polskiej, co nie sprzyjało dokładności) ${ }^{43}$, odczytał w tym miejscu tylko niezrozumiałe „Ra”. Nie zwrócił uwagi na literke „," (,g”) nadpisaną nad tymi literami. To niewielkie uzupełnienie wraz z wiedzą o pozycji Rahozy pozwala wnioskować, że w taki skrócony sposób zostało zapisane jego imię. Podobne skróty, często niezrozumiałe bez znajomości odpowiednich osób, są dobrze znane z późniejszych, liczniejszych dokumentów kancelarii hospodarskiej, gdzie służyły na oznaczenie np. panów obecnych przy podejmowaniu decyzji ${ }^{44}$. W prawym dolnym rogu natomiast, już dosyć wcześnie, w tym za Witolda, wpisywano imię osoby odpowiedzialnej za sporządzenie dokumentu (np. na nadaniu dla Jeśka Nieszewicza z 17 września 1427 r. - „Довкгирдъ правил” ${ }^{45}$ albo „Sam” w przypadku osobistego rozkazu hospodara - po analogii z formułami sprawczymi stosowanymi w dokumentach łacińskojęzycznych np. w kancelarii koronnej: „Dominus rex per se”, „Ad mandatum...”,

42 O tej polityce i stosownych dokumentach Witolda zob. J. Kurtyka, Repertorium podolskie. Dokumenty do 1430 roku [w:] idem, Podole w czasach jagiellońskich, Kraków 2011, s. 382-447; idem, Podole w średniowieczu i okresie nowożytnym: obrotowe przedmurze na pograniczu cywilizacji [w:] idem, Podole..., s. 124-128; В. Михайловський, Західне Поділля під володінням Вітовта у 1411-1430 роках: надавча політика у світлі документів [w:] До джерел. Збірник наукових пращь на пошану Олега Купчинського з нагоди його 70-річчя, т. 2, Київ-Львів 2004, s. 110-128; idem, Podole po Grunwaldzie (1410-1430): walka Witolda z Jagiełła [w:] Jogailos ir Vytauto laikai, red. Z. Kiaupa et al., Kaunas 2011, s. 117-125; idem, Еластична спільнота. Подільська шляхта в другій половині XIV-70-х роках XVI століття, Київ 2012, s. 97-107.

43 Edycję właśnie tego dokumentu, o ile można zrozumieć z lakonicznego passusu - „wszystkie były one ogłoszone drukiem z wyjątkiem jednego (z Bibl. IH PAN w Krakowie)" - zapowiadał M. Kosman (Dokumenty wielkiego księcia Witolda..., s. 141, przyp. 6), ale zamiar ten nie doszedł do skutku.

44 Zob. np. oryginał dokumentu Aleksandra Jagiellończyka z 22 II 1496 r.: Muzeum Narodowe w Krakowie, VIII - perg. nr 39.

45 Biblioteka XX. Czartoryskich w Krakowie, perg. nr 361; edycja В. Розов, Українські гралоти, т. 1: XIV і перша половіна XV в., Київ 1928, nr 59. 
„Ex commissione...”, „Ad relationem...”46. A więc Rahoza nie tylko pozostawał na służbie w oddziale ruskim kancelarii Witolda, ale towarzyszył hospodarowi w podróży w 1424 r. Może wtedy zapoznał się z realiami podolsko-wołyńskiego pogranicza Litwy z Królestwem Polskim (jeżeli wcześniej nie miał takiej wiedzy) ${ }^{47}$, co zapewne wykorzystał w poselstwach do króla w 1431-1432 r. Świdrygiełło, który niewątpliwie „odziedziczył” Rahozę po swoim wielkim poprzedniku Witoldzie.

\section{Aneks źródłowy}

[Punia, 14 XII 1418]

Wielki ksiaże litewski Aleksander Witold pisze do wielkiego mistrza zakonu niemieckiego [Michała Küchmeistra] w sprawie wydania złodziei Rusinów, którzy zbiegli do władztwa zakonnego. Streszczenie kancelarii wielkomistrzowskiej.

Oryg.: GSPK, OBA, nr 2873 (dawniej Varia 189), papier $223 \times 302 \mathrm{~mm}$, filigran - róg myśliwski (najbliższe analogie: G. Piccard, Wasserzeichen Horn, Stuttgart, 1979, Abt. VII, nr 114, 273; ten sam typ, ale wykazujacy mniejsze podobieństwo - tamize, nr 113, 116, 117, 272, 274-276, 279), in dorso streszczenie listu biskupa Liège pod nagtówkiem: Bisschoff czu Luttich schreibet.

Reg.: RHD, Bd. 1/1, nr 2873.

Uw.: Transkrypcję tekstów publikowanych źródet opartem na obecnych zasadach publikacji tekstów niemieckich z okresu późnego

46 Najobszerniej w tej kwestii zob. A. Hruša, Problemy badań kancelarii Wielkiego Księstwa Litewskiego lat 40. XV wieku-pierwszej ćwierci XVI wieku [w:] Belliculum diplomaticum IV Thorunense. Dyplomatyka staropolska - stan obecny i perspektywy badań, red. W. Chorążyczewski, J. Tandecki, Toruń 2011, s. 75-94; А.И. Груша, Документальная письленность..., s. 295-309; por. M. Kosman, Kancelaria wielkiego księcia Witolda..., s. 112-113; idem, Dokumenty wielkiego księcia Witolda..., s. 164.

47 Niestety, publikowany dokument nie zawiera cech, które w sposób jednoznaczny świadczyłyby o pochodzeniu jego pisarza z terenów białoruskich czy ukraińskich (za konsultację w tej sprawie składam serdeczne podziękowania prof. Wadimowi B. Kryśko z Instytutu Języka Rosyjskiego Rosyjskiej Akademii Nauk w Moskwie), nie ma jednak pewności, czy Rahoza własnoręcznie spisał ten dokument, czy tylko wydał odpowiednie polecenie i/lub skontrolował treść dokumentu. 
średniowiecza $i$ ruskich z terenu Wielkiego Księstwa Litewskiego - zob. Richtlinien für die Edition landesgeschichtlicher Quellen, hrsg. W. Heinemeyer, 2. Aufl., Marburg 2000; M. Thumser, Zehn Thesen zur Edition deutschsprachiger Geschichtsquellen (14.-16. Jahrhundert) [w:] Editionswissenschaftliche Kolloquien 2005/2007. Methodik-Amtsbücher-Digitale Edition - Projekte, hrsg. M. Thumser, J. Tandecki u.a., Publikationen des Deutsch-Polnischen Gesprächskreises für Quellenedition, Bd. 4, Toruń 2008, s. 13-19; D. Heckmann, Leitfaden zur Edition deutschsprachiger Quellen (13.-16. Jahrhundert), Preußenland 2013, Jg. 3, s. 7-13; Метадычныя рэкалендацыі па публікацыі рукапісных актавых кірылічных крыніч у Беларусі (XIII-XVIII cmcm., перыяд Вялікага княства Літоўскага), ауттар-складальнік A.I. Груша, Мінск, 2003.

\section{Also hat herczog Wytowdt geschreben}

Czum ersten, wir us euwirm briff czien, das ir ungutlichin von uns ufgenomen habt, als wir euch von den dreyn dyeben vorgeschreben haben, das ${ }^{a}$ euwir gute meynunge ofte $\mathrm{czu}^{b}$ ungutten wurden gewand ${ }^{c}$.

Item, wir habin euwir meynunge ny andirs gewand, denne als wir in euwirm briff befunden, und haben euch doruff von den dieben in gutter meynuge geschreben, vorkundigend euwir und unsir gelegheit, die czwusschen uns von alders her gehalden ${ }^{d}$ ist $^{e}$.

Item, das $\operatorname{sich}^{f}$ die frundschaft und gutte czwusschen uns mereten ${ }^{g}$.

Item, wir hofften, das ir uns der kleynen sachen nicht vorsaget, wend wir manchmol umb euwirn willen gethan haben und wulden ${ }^{h}$.

Item, wir nemet, das euch das etwas beweget, als wir in unsirm neesten briff euch geschrebin habin, also ir schriebt ok uns als deme, der nicht vornuft hette ${ }^{i}$.

Das haben wir dorumb gethan, das ir uns vor und nu schriebt, das die diebe nicht bie euch uff dem werder geweest ${ }^{j}$ weren, sunder do ir sie fundet czu Rangnith, do hatte sie der huwskumpthur gelertet ${ }^{k}$.

Item, was bedorfften sie geleite, do sie uff euwirm huwse woren, wend das vor ny gewonheit geweest ist ${ }^{l}$.

Item, das di diebe sulch gut nicht ${ }^{m}$ gebracht haben, ir sullet wissen, das unsir obirster Ruwssche schreiber Rahoza und ouch andir ${ }^{n}$, den do wol czu gloubin ist, bey erem eide $u_{n}{ }^{\circ}$ eyn sulchs gesagt habin.

Item, was were uns umb sulche buwen ${ }^{p}$ und so cleyne gut czu schrieben, wend wir des notdorft habin. 
Item, uns were leith, das umb eyne sulche kleyne sache irkeyn widdris undir uns enstunde.

Item, ir mochtet gedencken an di frundschaft und gutten willen, den wir mit euch von lenges gehabt habin, und ouch an euwir ${ }^{q}$ gelobde.

Item, meister Cunrad von ${ }^{r}$ Jungyngen sante dem konig von Polan czwene entlowfene folkener widdir.

a Nastepnie skreślone: $w$; ir uns schreibt recht sam wir nicht vornuft hetten und.

${ }^{b}$ Poprawione $z$ un.

c Cały akapit zakreślony, na lewym marginesie obok znak w postaci krzyża w kole, poniżej litera a (?).

${ }^{d}$ Nadpisane nad skreślonym gelegen. litera c.

e Caty akapit zakreślony, na lewym marginesie obok znak w postaci krzyża, powyżej

$f$ Nadpisane nad skreślonym das.

$g$ Na lewym marginesie obok znak $w$ postaci krzyża i poprawiona litera $\mathrm{f}(?)$.

${ }_{h}$ Na lewym marginesie obok znak w postaci krzyża i litera g, poniżej stowo nota $w$ ramce; caty akapit zakreślony.

${ }^{i}$ Na lewym marginesie obok znak $w$ postaci krzyża $w$ kole, powyżej litera b; caty akapit wykreślony.

j Nastepuje skreślone sien.

${ }^{k}$ Na lewym marginesie obok litera d.

${ }^{l}$ Na lewym marginesie obok litera e.

m Nadpisane nad skreślonym nif.

$n$ Następuje skreślone eyn fr (ostatnie litery też moga być odczytane jako st).

- Nastepuje skreślone ge.

p Nastepuje skreślone zu sc.

$q$ Następuje skreślone gelode.

$r$ Nastęuje skreślone Jungyng.

2

Jałtuszków, 22 VIII 1424

Wielki ksiażę litewski Aleksander Witold nadaje Sankowi, synowi Andrzejka Radiewicza, wieś Czelijów i zapisuje mu na niej 40 grzywien ziemskich groszy.

Oryg.: Biblioteka PAU i PAN w Krakowie, dokument pergaminowy $\mathrm{nr} 375$, pergamin $227 \times 130 \mathrm{~mm}$, pod tekstem ślady po odciśniętej pieczęci $w$ wosku czerwonym o średnicy $32 \mathrm{~mm}$, w tym miejscu zachowat się przeciagnięty przez dwa wertykalne nacięcia pasek pergaminowy, poniżej wspótczesna pieczęć biblioteki PAN, 
nota ołówkiem: Sygn. dypl. 375. In dorso w lewej części karty starannym, archaicznym półustawem właściwym dla ksią: Я, игоумень Василнь ніколиньски, држал есми приви | ль^ Чельлвьского. Пришлі|его два сьнове, допытжючисл прівилА, Бенібо и $2^{a}$ Федорь|и Павель, безь тых 3 братеникохь|абы не дато никомх (na przedostatnim i ostatnim wierszu pod nota ślady zmytych słów pisanych takim samym pismem). W części środkowej noty: \#|Pisanie seu prawo od x. JMci Wytowta, a to na sioło Wielijow, ze |wszystkiemi przynaleznosciami, | dany ur. Sachnowi Andrzejiwizowi, na wiecznosc uczyniony. $\mid \mathrm{A}^{\circ}$ Deest. $2^{b} .22$ Augusti.| Po rusku. W Ołkoszkowie. Poniżej tej noty $w$ dolnej części: Wielijow, w prawej części, pobliżej górnej krawędzi: 22/VIII 1424.

Wyd.: Vitoldiana, nr 102 (w transliteracji łacińskiej, z błędami).

Reg.: K. Dziwik, Katalog dokumentów pergaminowych Biblioteki Polskiej Akademii Nauk w Krakowie, cz. 1: Dokumenty z lat 1113-1571, Wroctaw 1966, nr 47; J. Kurtyka, Repertorium podolskie..., nr 164 .

Uw.: zob. $n r 1$.

Мы, великии“ кн(^)зь Витовтъ, дали єсмо сюю нашоу грамотоу Санкоу Анъдрьиковоу|с(ы)ну Радевича, што есмо ему дали село Челиевъ $^{c}$. А коли быхоли имьли оу него|тое село $w m$ нАти, и мы имаемъ дати сорокъ гривенъ земъскими гро|шми.

А псан в Олтушъковђ, во вторник $\kappa^{*}$ оу тыижд(е)нь ${ }^{d}$ по Оуспеньи с(вА)тьи |Б(огороди)ци, авгоуста оу 22 , индикта оу 2.

Раг(оза).

a Wpisane nad wierszem.

b Poprawione $z 6$.

c e poprawiona $z$ и.

d Po literze ж nastepuje niby niedopisana e lub o.

\section{Abstract}

Rahoza. A contribution to the history of the grand-dukal chancery and court in Lithuania in the epoch of Vytautas

The article is devoted to Rahoza, a man appearing several times in the milieu of grand duke Švitrigaila (Świdrygiełło) of Lithuania during his 
reign in Vilnius (1430-1432). Since his origins were unknown, and his name's ethymology is Ruthenian, I tended to suppose that he came to Lithuania together with Švitrigaila from the Chernigov land where he had ruled in 1420-1430. However, a new source was found among the papers of the Königsberg archive (nowadays preserved in Berlin), a summary of grand duke Vytautas' letter to grand master of the Teutonic Order Michael Küchmeister written in 1418, which mentions Rahoza as the supreme Ruthenian scribe (,obirster Ruwssche Schreiber”) of the grand-ducal chancery. This mention sheds an important light on the structure and organization of the Ruthenian department of this chancery. It allowed to reveal one more mention of Rahoza, namely his ,signature” in a shortened form on Vytautas' document of donation for Sanko in Podillya (Podole), issued in 1424 . 